\title{
Notice of Documents Preserved in the Record Office, at Malta
}

\section{A. Milward}

To cite this article: A. Milward (1850) Notice of Documents Preserved in the Record Office, at Malta, Archaeological Journal, 7:1, 369-373, DOI: 10.1080/00665983.1850.10850790

To link to this article: http://dx.doi.org/10.1080/00665983.1850.10850790

曲 Published online: 06 Dec 2014.

Submit your article to this journal $\pi$

Q View related articles $\llbracket$ 
Ridware; given in Shaw's Staffordshire, vol. i., 165\%; and by a plea roll of the 15th of Richard II., quoted in Nichols' Leicestershire, in a note to the pedigree of "Appleby of Appleby" (vol. iv, pt. 2, p. 442). This last bears record, that Thomas Stafford, miles, and Alice, his wife, were summoned, \&c., " ad respondendum Nicholao Longford, chivaler, et Margerie uxori de placito, quare cum iidem Nicholaus et Margeria et Thomas et Alicia, insimul et pro indiviso teneant manerium de Penkeston et Normanton cum pertin' de hereditate que fuit Johannis Sulny, militis, fratris predictarum Margerie et Alicie, cujus heredes ipse sunt, iidem Thomas et Alicia partitionem inde inter eos faciendo contradicunt, \&c."

On comparing the above pedigree and the facts illustrating it, with the costume of the figures in the church, there seems every probability that the effigies commemorate two of the earliest De Sulneys, and the last knight of the name, who died in the reign of Richard II. It might not, perhaps, be too venturous to assume, that the knight of freestone, in the south aisle, was Sir Norman himself, the founder of his house, and the warrior in banded mail, his son Sir Alfred. And what a lesson for founder and warrior: the founder was buried away for years among the rubbish of the churchyard, and the warrior was " removed from the nave into a lumberroom on the north side of the chancel!"

J. HEWITT.

NOTICE OF DOCUMENTS PRESERVED IN THE RECORD OFFICE, AT MALTA.

Amongst the archives preserved in the island of Malta there exist numerous documents of more than ordinary value, alike to the historian and the antiquary. During a visit which I paid to this Record-office in the winter of $1848-49$, I was struck with their varied character, as also with the interesting evidences, connected with English Annals, preserved in this depository. I am induced to hope that the following brief notice may be acceptable to the readers of the Journal, and serve to invite attention to this very curious and important collection.

Of these, very little is, however, known; for persons 
resident on the island are in general very deficient in education, and in anything like an interest for intellectual pleasures or pursuits; while the winter visiters scarcely remain long enough to become acquainted with the existence of such documents. Under these circumstances it is particularly creditable to the present keeper of the records, Mr. Luigi Vella, that he has, unassisted and without encouragement, drawn up detailed catalogues of all the documents under his care; and so complete has been the result of his labours, that he is able to turn to abstracts of the various papers, and by means of indices to refer to much information on any particular name or subject. In England, a work of so much labour would have secured encouragement and commendation; but I fear that the English residents in Malta, even if they were acquainted with what he has done, would requite such researches with indifference, possibly even with ridicule.

It is not in my power to give a full account of the contents of the Record-office, but I believe that I can mention enough to show that there are many very curious and valuable documents there preserved, to which the attention of English antiquaries might be addressed with advantage ; the praiseworthy labours of Mr. Luigi Vella might thus be turned to account, and he might be stimulated to further industry.

The most important series of documents is comprised in six thick volumes of records, chiefly on parchment, consisting of charters from sovereigns and princes, grants of land and other public instruments connected with the Order of St. John, from its first establishment by Pope Pascal II., whose original Bull is in admirable preservation. The greater part of the papers in these six volumes were published at Rome by Padre Paolo, and copies of his work exist in the Public Library and the Secretary's Office. Many, however, have been omitted, and, in Mr. Vella's opinion, without sufficient reason.

A selection of the Bulls of the Popes connected with the Order has also been published.

The following collections have never been published, or even, as it is believed, been properly examined.

Two volumes of papers connected with the Island of Malta, before it came into the possession of the Knights, forming a series commencing with the year 1397, and carried down to the beginning of the sixteenth century. 
A Book of Privileges of the Maltese, compiled about two hundred years ago.

From these volumes Mr. Vella has drawn up an account of the civil constitution of Notabile, the ancient capital of the island, now denominated Citta Vecchia. This constitution was called the "Universita" and was recognised by the Knights, and its forms kept up for a long period. The Parliament House - a fine building-still exists in the almost deserted city of Citta Vecchia. In later times there was an "Universitá" of Vittoriosa, and of Valetta.

There are several volumes of original letters, many of them connected with celebrated names. There are some from the Viceroys of Sicily. About thirty are from sovereigns of England, and among them, several from Henry VIII,, with his well-known bold signature. These royal letters principally consist of mere compliments on the accession of the Grand Master ; but a few are of more interest, and amongst them is that of which a copy accompanies these observations. Under the date 1725 , is one from the Pretender, then at Rome, who appears to have been on good terms with the Grand Master, and writes to request that he would not present to the grand priories of his (the Pretender's) dominions, or appoint coadjutors without first consulting him. On making this request to the Pope, he had been referred to the Grand Master.

There are three letters from Charles II., claiming civilities for his fleet and the admiral, John Narbrough. The latter also appears to have written in a somewhat spirited manner on the occasion of a dispute about a salute to the English flag. On June 10, 1720, the Chevalier Laval writes from London to the Grand Master respecting a representative of the Order at some congress, and also on a dispute about a flag.

There are also a large number of Processes of Nobility, which contain much valuable information respecting the descent and connection of families. Mr. Vella has taken the trouble of making a separate list of references to those papers which contain any allusions to English families, and these might possibly prove of considerable interest.

There is also a volume of the fifteenth century, containing the accounts of the Commanderies. It is a continuation of an older and still more interesting volume, which has by some means found its way into the Public Library; the latter 
gives the accounts of the property belonging to the Order in England and Scotland. Unfortunately these accounts are very difficult to decypher. I remember, however, looking over it in company with a Scotch gentleman, who had edited various antiquarian works, and with another gentleman from Northumberland. The Scotchman read the MS. with tolerable facility; my friend from the North repeatedly identified certain allusions with property that he knew, and felt much interest in the book. There is also much that is valuable in the statement of the different prices paid for commodities, labour, \&c.

In the volumes of Deeds are many curious specimens of ancient tissues of silk; the red and yellow colours are still bright and in beautiful preservation, although six or seven centuries have passed over them. I have been informed that there are papers belonging to the Order in Sicily, Rome, and Constantinople. Applications have been made at the latter place for copies, but I do not know that any have been received, or are likely to be very anxiously sought for.

The following letter from James II., although some may possibly regard it as not strictly within the limits of archaeological inquiries, may prove, I hope, not without interest to the members of the Institute ; and as it brings to light facts, which I have not seen alluded to elsewhere, it may be selected as one of the evidences connected with our own country preserved in this depository, well deserving of publication.

A. MILWARD.

Copy of a Letter from James II. of England to the Grand Master of the Order of St. John at Malta, July 13, 1689.

\section{[Duplicata.]}

Mon Cousin,-Nous avons receu avec une satisfaction extraordinaire votre obligeante lettre du 4 d'Avril, dans laquelle outre l'estime et la bonté que vous temoignes pour notre jeune fils ${ }^{1} \mathrm{~J}$ ames, nous observons avec plaisir la passion et le zele que vous avez de nous servir et ${ }^{2}$ gratifier en ce rencontre; c'est pourquoi nous nous sentons obligez par touttes les raisons de justice, aussy bien que par notre inclination particuliere, de vous en marquer nos reconnoissances. Ce que nous faisons icy avec toutte la sincerite d'un cœur zele pour le bien de la Religion, et particuliérement pour la gloire de votre ordre illustre, qui en est un si puissant appuy, et a l'agrandissement du quel nous nous ferons toujours un plaisir singulier de contribuer dans toutes les occasions; Et, afin que notre fils puisse etre un

1 Or possibly filz?

2 Indistinct in the MS. The reading appears by the context to be Et. 
sujet digne de servir Dieu et sa Sainte Eglise, dans la dignite que vous voulez bien luy accorder de Grand Prieur d'Angleterre, nous ne luy laissons point perdre de temps, car actuellement il fait une campagne assez rude et dangereuse contre nos sujets rebellers ${ }^{3}$ qui sont en mesme temps tous ennemis de la Religion, et a ce que rien n'y manque, le Bref que notre Saint Pere a eu la bonte de nous accorder sur ce sujet est envoyé. Au reste pour le succes de nos affaires nous nous recommandons aux prieres et aux voeux de tout votre ordre, et prions aussy Dieu qu'il vous ait en sa sainte garde.

Donne en notre Cour, au chateau de Dublin, le $13^{\text {me }}$ de Juillet, 1689.

[ Votre affectionne Couzin, JACQUES R. ]

The subscription within brackets appears to be the autograph of James.

3 The penultimate $r$ in this word is rather indistinct in the MS.

Monumental Purtraiture of Wisselus de Smalenburg, at Boston, LinCOLNSHIRE. (See page 54.)

The exact position in which this remarkable specimen of this class of sepulchral effigies was discovered, is stated in a short letter, dated Dec. 7, 1795, and addressed to Mr. Urban by "Lincolniensis" (Gent. Mag., vol. lxv., part II., p. 995).

The writer states that a tombstone, with the inscription, Hic jacet Wisselus, \&c. (as before given) was dug up on August 28 of that year, in a pasture adjoining to " the Hussey Tower Pasture," at Boston, belonging to Thomas Fydell, Esq. The slab lay at the depth of about eight inches beneath the surface.

By an inadvertent oversight, the curious inscribed sword, from the river Witham, Lincolnshire, presented to the Institute by the obliging keeper of the archives of the see of Lincoln, R. Swan, Esq., was given as measuring only 18 inches in length. (See page 290.) The entire length of this remarkable weapon is 3 feet 2 inches, the length of the blade is 2 feet 8 inches; the blade is of more than ordinary width, the broadest part measuring nearly $2 \frac{1}{2}$ inches.

We hope that some of our readers, versed in the decyphering of middleage enigmas, may supply the interpretation, hitherto unattempted, of the characters upon this fine sword. They are represented with the greatest possible accuracy by the woodcut, given as above. Commencing from the hilt they appear to read thus :- the $M$, the $G$ following it, and the $A$ are inverted. NDXOXGHMDNGHDXORAI 